\title{
NATIONAL SECURITY CONCERNS AS AN EXCEPTION TO EU STANDARDS ON DATA PROTECTION
}

\begin{abstract}
ARACELI TURMO*
Discussions on the appropriate fundamental rights standards in the EU and the need to take into account conflicting interests are increasingly being reframed as debates on the conflict between the primacy of EU law and the constitutional standards of the Member States. One example of this reframing is the French administrative supreme court's decision following the ECJ judgment in La Quadrature du Net. The Conseil ruled that the EU standards set in that judgment must be reviewed, at the national level, with regard to a national understanding of security concerns and the requirements of the fight against terrorism. Thus, constitutional requirements related to public security may be relied upon to argue for a lower standard of protection of personal data than those which the ECJ requires. As this decision shows, the ability of corporations and Governments to rely on litigation before national courts to challenge the standard of protection set at the EU level creates a significant risk, not only for the uniformity of $E U$ law, but also for the protection of the rights of individuals.
\end{abstract}

\section{INTRODUCTION}

In his contribution titled 'Lower Instance National Courts and Tribunals in Member States, and Their Judicial Dialogue With the Court of Justice of the European Union', ${ }^{1}$ Graham Butler examines the pertinence of greater hierarchical authority from the European Court of Justice over national implementations of EU law. He examines the risks involved in litigants forming strategies to use national courts and judicial systems as an indirect means to avoid, or even fight against, EU standards related to the protection of personal data. This paper highlights the importance of the participation of national courts if the EU is to uphold the standards set out in judgments such as Schrems $I^{2}$ and Schrems $I I .^{3}$ If national courts can be used as a means for corporations or national governments to avoid EU standards which are seen as too restrictive to trade, innovation or surveillance, the effectiveness of the ECJ's efforts will be greatly diminished.

\footnotetext{
* Assistant Professor, University of Nantes. This paper partly draws on the analysis presented in a more detailed case note forthcoming in the Common Market Law Review: Araceli Turmo, National security as an exception to EU data protection standards: The judgment of the Conseil d'État in French Data Network and others' (2022) CMLRev. 59 (forthcoming).

${ }^{1}$ Graham Butler, 'Lower Instance National Courts and Tribunals in Member States, and Their Judicial Dialogue With the Court of Justice of the European Union' (2021) 4(2) Nordic Journal of European Law 19.

${ }^{2}$ Case C-362/14 Maximillian Schrems v. Data Protection Commissioner (Schrems I) ECLI:EU:C:2015:650.

${ }^{3}$ C-311/18 Data Protection Commissioner v Facebook Ireland Ltd and Maximillian Schrems (Schrems II) ECLI:EU:C:2020:559.
} 
The judgment of the French Conseil d'État, published on 21 April 2021, ${ }^{4}$ in the case which jointly gave rise to the La Quadrature du Net judgment ${ }^{5}$ once again proves the existence of these risks. Although this case had to do with the protection of personal data from state interventions concerning the collection and access to metadata in the EU, rather than on the standards applicable to international transfers of personal data, its treatment by the French administrative supreme court raises concerns related to those presented in G. Butler's contribution. In this case, the French judicial system was successfully used by the Government as a shield from the full reach of EU fundamental rights standards. Moreover, the reasoning followed to justify this decision may prove to be a tempting alternative for national supreme courts and governments which are uneasy with aspects of ECJ case law. This is particularly worrying at a time when the ability of EU institutions to ensure compliance with core tenets of primary law is called into question. The 'cross-pollination' of Eurosceptic lines of reasoning across national courts could become a significant hurdle in the fight to protect the integrity of European Union law, as evidenced by the reference to the BVfG case law ${ }^{6}$ in the Polish Trybunał Konstytucyjny's infamous 7 October 2021 ruling. $^{7}$ In these judgments, the national court have resorted to ruling the case law of their EU counterpart to be ultra vires, a rather blunt but efficient instrument in removing the efficacy of parts of EU law in a given Member State. The French Government had in fact encouraged the French supreme court to go down the same path in reaction to La Quadrature du Net, in order to preserve French regulatory provisions allowing the indiscriminate gathering and retention as well as relatively unrestricted access to this metadata by security and intelligence services.

The approach followed by the Conseil d'État is less obviously confrontational, but ultimately more insidious ${ }^{8}$ and it could prove to be more efficient in challenging the implementation of EU fundamental rights standards within the Member States. The French court has established a new exception to the primacy of EU law, justified by national security concerns: whenever the French judges are not satisfied that EU standards are compatible with these concerns, as defined by French authorities, they reserve the right not to implement them and thus to set aside the balance established by the ECJ between fundamental rights and the need to fight against crime and ensure security and public order. Like the ultra vires accusations, this decision is based on a challenge to the EU's competences. At the core of the Conseil d'État's decision is the idea that the EU is not capable of setting the balance between the protection of personal data and security, because the EU has very limited competences in the fight against crime, and the preservation of public order and security is a policy field that mostly remains in the hands of the Member States. National courts are the

\footnotetext{
${ }^{4}$ CE Ass., 21 April 2021, Req. no. 393099. For a more complete analysis of this judgment, see inter alia: Loïc Azoulai and Dominique Ritleng, “'L'État, c'est moi”. Le Conseil d'État, la sécurité et la conservation des données' [2021] Revue trimestrielle de droit européen 349, 354.

5 Joined Cases C-511/18, C-512/18 and C-520/18 La Quadrature du Net and Others v Premier ministre and Others (La Quadrature du Net) ECLI:EU:C:2020:791. Significantly, one of the cases was initiated by a preliminary reference on very similar provisions in Belgium, but the Belgian Constitutional Court had had a very different reaction to the ECJ judgment.

${ }^{6}$ Bundesverfassungsgericht, Judgment of the Second Senate of 5 May 2020, 2 BvR 859/15, 2 BvR 1651/15, 2 BvR 2006/15, 2 BvR980/16.

7 Trybunał Konstytucyjny, Judgment of 7 October 2021, K 3/21.

8 Shahin Vallée and Gerard Genevoix, 'A Securitarian Solange' (Verfassungsblog, 25 April 2021)

<https://verfassungsblog.de/a-securitarian-solange/> accessed 11 December 2021.
} 
more appropriate locus for the debate (1), and national concerns such as those related to security are acceptable justifications for exceptions to EU law on personal data protection (2).

\section{NATIONAL COURTS AS THE LOCI OF CHALLENGES TO THE SCOPE OF EU COMPETENCES ON PERSONAL DATA PROTECTION}

Like other national supreme courts and constitutional courts, the Conseil d'État relies on its own understanding of the distribution of competences between the EU and its Member States in order to challenge the European Court of Justice's case law and its legitimacy under the principle of conferral. However, the French court avoids the direct confrontation of an ultra vires finding and chooses instead to ignore the ECJ's exercise of EU competences in the area which it deems to be outside their scope. In practice, in the La Quadrature $d u$ Net judgment and the rest of the case law concerning EU standards for the protection of personal data from national authorities, this means ignoring the balance chosen by the ECJ between privacy and the protection of public security and holding that, by nature, the ECJ was unable to determine the contents of the latter. Instead of complying with a balance established at the European level, according to the Conseil d'État, national authorities must be capable of establishing their own balance between the (fundamental rights) standards set at the EU level and the security concerns defined within the Member State.

The reasoning presented by the Conseil d'État is a reply to the arguments presented by the French Government, which clearly sought to rely on this national court in order to prevent the EU standards from being implemented fully. By asking the judges to hold that the ECJ had ruled ultra vires, and encouraging them to determine whether or not they must follow the rules established in EU law, the Government was relying on the Conseil's willingness to challenge the ECJ's own understanding of EU competences in this area. The fact that a Government which otherwise likes to present itself as very pro-European was willing to challenge EU standards on personal data to the extent that it would ask its highest court to set them aside is a very worrying sign. It signals that Member States are far from ready to accept EU standards on data protection which restrict the powers of police and national security forces. It also weakens that the ability of EU institutions to establish common standards for the protection of privacy and even to carry out international negotiations in this area: to what extent is the EU credible in requiring partners such as the United States to adapt to a higher degree of protection of personal data, when it is unable to convince its own Member States that it has struck an appropriate balance with security interests?

The Conseil d'État's choice to avoid direct conflict, in the form of an ultra vires decision which could easily have justified infringement proceedings against France, does show an attempt at reaching a compromise position between the Government and the ECJ. ${ }^{9}$ However, this debate should not be taking place before national courts, after Governments

\footnotetext{
9 Jacques Ziller, 'Le Conseil d'État se refuse d'emboiter le pas au joueur de flûte de Karlsruhe' (Blog Droit Européen, 23 April 2021) < https://blogdroiteuropeen.com/2021/04/23/le-conseil-detat-se-refuse-demboiterle-pas-au-joueur-de-flute-de-karlsruhe-par-jacques-ziller/> accessed 11 December 2021.
} 
have failed to make their case convincingly before the ECJ (or, at any rate, to succeed in convincing the judges that they should strike a different balance between privacy and security). EU standards should be debated and determined at the EU level and, if they are to have tangible effects, must be followed across the Member States. Allowing Governments to renegotiate such standards before national courts, which are institutionally more likely to be sensitive to State-specific concerns and, in the case of the Conseil d'État, inherently closer to the national executive, would be antithetical to the duty of sincere cooperation set out in Article 4(3) TEU. It also poses a major threat to the EU's law-making abilities and its ability to establish fundamental rights standards within the scope of its own competences.

\section{NATIONAL SECURITY CONCERNS AS EXCEPTIONS TO EU FUNDAMENTAL RIGHTS}

The strategy which focuses on bringing the debate on the appropriate balance between the protection of personal data and security before national courts relies on the belief that Member States' courts will be more receptive to national security concerns than the ECJ. Moreover, the very nature of the legal grounds raised before the Conseil d'État and the judges' reasoning tilts the balance in favour of security concerns. In the framework introduced by the Conseil d'État, the only focus of the additional test carried out by the national court is national security.

The aim of the challenge and the Conseil's response is not really to propose a French perspective on the appropriate balance between privacy and security in EU law. Rather, the Conseil d'État was invited to centre security concerns, as defined by the French Government, on the understanding that the ECJ had given too much weight to fundamental rights. The EU standard is not presented as a legitimate attempt to strike a balance between the conflicting goals at issue, but as excessively focused on personal data protection. All this is justified by a presumption that the EU and, more specifically, the ECJ, is inherently incapable of taking into account the security concerns raised by Governments because it is biased towards fundamental rights protection and does not have sufficient competences in the fields of public order and security in order to develop a clear understanding of that side of the debate. In effect, the approach chosen by the Conseil d'État is based on the idea that the standard set at the EU level is inherently flawed and cannot be unquestioningly accepted by national authorities, which must be able to add a layer of judicial review based on their own understanding of security concerns in order to construct an appropriate balance applicable within each Member State.

By relying on an exception to the implementation and thus to the primacy of EU law, the Conseil d'État affirms the superior legitimacy of national standards regarding public security over the equivalents established at the level of the EU. This is particularly apparent in the justification given for this exception, which draws from the Arcelor case law. ${ }^{10}$ Under that case law, similarly to what has been established by other supreme and constitutional courts, an exception to the primacy of EU law was permitted where it was necessary to

\footnotetext{
${ }^{10}$ CE, ass., 8 févr. 2007, Arcelor, Req. n²87110. On this judgment, see inter alia Paul Cassia, Le droit communautaire dans et sous la constitution française' [2007] Revue trimestrielle de droit européen 378; Anne Levade, 'Le Palais-Royal aux prises avec la constitutionnalité des actes de transposition des directives communautaires’ [2007] Revue française de droit administratif 564.
} 
ensure the protection of national constitutional standards, ie, where a provision based on EU law is compatible with EU fundamental rights standards but incompatible with more stringent national standards. In this ruling, this exception is reversed, in order to allow provisions of national law which are incompatible with EU fundamental rights standards to stand, if they are deemed necessary to protect different national constitutional standards: in this case, ill-defined goals related to security concerns and the fight against organised crime and terrorism. Setting aside the issue of the justification for this ruling from the perspective of French constitutional law, ${ }^{11}$ this approach raises serious concerns. It enshrines into French public law the idea that any type of (broadly defined) constitutional norm or objective can justify an exception to EU fundamental rights standards, not only when national authorities believe their understanding of a specific right provides better protection, but also when they choose a lower level of protection than the one which EU institutions are trying to enforce. ${ }^{12}$

The approach chosen by the Conseil d'État relies on the national judges carrying out their own verification of the extent to which EU standards on personal data protection affect the State's ability ensure public security and fight against crime. In practice, this means national courts will, when reviewing national provisions, first apply the EU standard as they understand it, second check whether the results of this review make it excessively difficult to reach the constitutional objective at issue. In this case, the Conseil d'État ruled that only a very limited number of the provisions it was reviewing were incompatible with the standard set by the CJEU. But the broader implications of such two-pronged reviews could be significant as they seek to give national judges significant leeway with regard to EU standards. The attempts to establish a high level of protection of personal data in EU law could easily be thwarted if all national courts give precedence to national security objectives and allow themselves to decide, on a case-by-case basis, whether or not to implement the standards set by the ECJ. The scope of the exception is also unclear: with regard to the justification put forward by the French court, which simply refers to the existence of a conflicting constitutional objective, it seems entirely possible to imagine raising similar exceptions based on different values and principles, such as a national understanding of a different fundamental right, or concepts such as legal certainty or proportionality.

A more recent decision by the French Conseil constitutionnel, on the duty of air carriers to reroute third country nationals who are refused entry into the French territory, illustrates the risks associated with such broad exceptions to primacy being established by national courts. In this case, the Conseil constitutionnel followed its earlier case law indicating that it would abstain from reviewing EU law instruments with regard to national norms, except when they conflict with a principle which is 'inherent to the constitutional identity' of France. It then went on to hold that the prohibition of any delegation of general administrative police powers inherent to the exercise of 'public force' to private entities is such a principle, derived from Article 12 of the 1789 Declaration of the Rights of Man. ${ }^{13}$

\footnotetext{
${ }^{11}$ In particular, the reference to the concept of 'objectives of a constitutional value' and to Article 12 of the Declaration of the Rights of Man of 1789 is not fully convincing: Édouard Dubout, 'Le Conseil d'État, gardien de la sécurité' (2021) chron. 18 Revue des droits et libertés fondamentaux

< http://www.revuedlf.com/droit-ue/le-conseil-detat-gardien-de-la-securite/> accessed 11 December 2021.

12 Anastasia Iliopoulou-Penot, 'La conservation généralisée des données de connexion validée, le droit au désaccord avec la Cour de justice revendiqué' (2021) 24 JCP 659.

${ }^{13}$ CC Decision 15 October 2021, n²021-940 QPC, Société Air France, para. 15.
} 
According to the Conseil constitutionnel's own commentary of this decision, the principle is part of France's constitutional identity because there is no equivalent norm in EU law: ${ }^{14}$ the concept does not indicate that the principle is particularly central or historically important in French constitutional law, but simply that it is absent from, or insufficiently protected in, the EU legal order. In this instance, the Conseil ruled that this principle was not violated by the legislative provisions implementing EU law. However, this decision denotes the flexibility of exceptions based on 'constitutional identity' which, combined with the ability of constitutional and supreme courts to establish or elaborate on constitutional principles, could lead to a multiplication of opportunities for the national review of EU law. Under this reading of Article 4(2) TEU and of French public law, any of the multiple principles established in the case law of the Conseil constitutionnel is capable of justifying an exception to primacy if national institutions believe that it is not recognised, or even not sufficiently well protected, under EU law.

Should this type of reasoning become common in national courts, it would allow a variety of political and legal considerations stemming from more or less specific national contexts to impede the appropriate implementation of EU standards for the collection, retention and access to personal data by governments and corporations. The temptation for governmental and corporate actors could become great to rely on such national layers of judicial review to prevent the full implementation of EU law and thus to prevent the ECJ and other EU institutions from constructing and promoting a coherent and ambitious framework for the protection of this data. If these challenges to EU law are successful, they could become a significant cause for variation between the Member States, which would constitute a particularly challenging development at a time when the EU is trying to defend its standards on an international stage.

${ }^{14}$ Conseil constitutionnel, Commentaire de la Décision n²021-940 QPC du 15 octobre 2021

< https://www.conseil-constitutionnel.fr/decision/2021/2021940QPC.htm.> accessed 11 December 2021. 


\section{LIST OF REFERENCES}

Azoulai L and Ritleng D, “'L'État, c'est moi”. Le Conseil d'État, la sécurité et la conservation des données’ [2021] Revue trimestrielle de droit européen 349.

Cassia P, 'Le droit communautaire dans et sous la constitution française' [2007] Revue trimestrielle de droit européen 378.

Dubout É, 'Le Conseil d'État, gardien de la sécurité' (2021) chron. 18 Revue des droits et libertés fondamentaux < http://www.revuedlf.com/droit-ue/le-conseil-detat-gardien-de-lasecurite/> accessed 11 December 2021

Iliopoulou-Penot A, 'La conservation généralisée des données de connexion validée, le droit au désaccord avec la Cour de justice revendiqué' (2021) 24 JCP 1152.

Levade A, 'Le Palais-Royal aux prises avec la constitutionnalité des actes de transposition des directives communautaires’ [2007] Revue française de droit administratif 56.

Vallée S and Genevoix G, 'A Securitarian Solange' (Verfassungsblog, 25 April 2021) $<$ https://verfassungsblog.de/a-securitarian-solange/>accessed 11 December 2021.

Ziller J, 'Le Conseil d'État se refuse d'emboiter le pas au joueur de flûte de Karlsruhe', (Blog Droit Européen, 23 April 2021) < https://blogdroiteuropeen.com/2021/04/23/leconseil-detat-se-refuse-demboiter-le-pas-au-joueur-de-flute-de-karlsruhe-par-jacquesziller/> accessed 11 December 2021. 